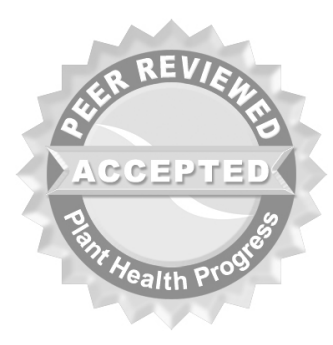

(c) 2008 Plant Management Network.

Accepted for publication 12 July 2008. Published 6 October 2008.

\title{
Evaluating the Pathogenicity of Pythium vexans Isolates from Fraser Fir in North Carolina
}

Kelly L. I vors, Assistant Professor and Extension Specialist, Department of Plant Pathology, North Carolina State University, Fletcher, NC 28732; Z. Gloria Abad, Lead Scientist and Plant Pathologist, USDA-APHIS-Molecular Diagnostics Laboratory, Beltsville, MD 20705; and D. Michael Benson, Professor, Department of Plant Pathology, North Carolina State University, Raleigh, NC 27695

Corresponding author: Kelly L. Ivors. Kelly_Ivors@ncsu.edu

Ivors, K. L., Abad, Z. G., and Benson, D. M. 2008. Evaluating the pathogenicity of Pythium vexans isolates from Fraser fir in North Carolina. Online. Plant Health Progress doi: 10.1094/PHP-2008-1006-01-RS.

\begin{abstract}
The pathogenicity of Pythium vexans isolates collected from fir samples with typical root rot symptoms in North Carolina was evaluated on Fraser fir seedlings (Abies fraseri). Two replicated pathogenicity trials involving seven treatments were conducted in the lath house and greenhouse. Although the P. vexans isolates examined in these trials were able to colonize Fraser fir root systems, they did not cause mortality or incite root rot symptoms. In comparison, Phytophthora cinnamomi, a known aggressive pathogen of Fraser fir, caused severe root rot symptoms in all plants. These experiments provided no evidence that $P$. vexans is a pathogen of Fraser fir.

I ntroduction

Christmas trees are an important nursery crop in the United States, representing a \$211 million industry in 2006 (8), with North Carolina leading the nation in production of Fraser fir. Phytophthora root rot and stem canker, caused by several Phytophthora spp., has been associated with significant damage to Fraser fir since the 1960s (4). In North Carolina, Phytophthora cinnamomi, P. citricola (10), P. cactorum (2), and P. drechsleri (1) have been isolated from symptomatic roots and surrounding field soils, although $\mathrm{P}$. cinnamomi accounted for most of the disease incidence in Fraser fir in a 1999 survey (2).

During the 2005 growing season, 113 samples of Fraser and Canaan fir (Abies balsamea var. phanerolepis)) with typical root rot symptoms were collected throughout the state of North Carolina and submitted to the Plant Disease and Insect Clinic (PDIC) at NC State University for disease diagnosis by plating of root systems on selective media $\left(\mathrm{P}_{10} \mathrm{ARPH}\right)(5)$ for isolation of Pythiaceous organisms; diagnoses were as follows: Phytophthora species (51 samples), no pathogen (21 samples), Pythium vexans (13 samples), other pathogens or disorders (13 samples), other Pythium species (6 samples), and both Pythium and Phytophthora species (9 samples). Although Pythium undulatum has been previously reported to cause root disease on Noble fir (Abies procera) in Ireland (9), North Carolina Christmas tree specialists and agents were unsure how to respond to Abies samples confirmed with P. vexans. The objective of this research was to evaluate the pathogenicity of P. vexans on Fraser fir. Phytophthora cinnamomi, known as an aggressive pathogen on this host, was used as a standard for comparison.
\end{abstract}

\section{Preparation of I noculum, I noculation Procedures, and Pathogenicity Assays}

Seven treatments were evaluated in two separate trials. On 20 April 2006 (trial 1), greenhouse-grown Fraser fir plugs were individually transplanted in $3 / 4$ gal pots containing six parts pine bark to one part peat moss and placed in a 
randomized complete block design with 14 replications in a lath house at the NC State University Horticultural Field Lab in Raleigh, NC. On 19 October 2006 (trial 2), greenhouse-grown Fraser fir plugs were individually transplanted in Anderson band pots (OBC Northwest Inc., Canby, OR) with six parts pine bark to one part peat moss and placed in a randomized complete block design with 10 replications in a NC State University greenhouse in Raleigh, NC. For both trials, isolates were grown on CMA for one week, transferred to flasks containing autoclaved rice grains and incubated for 10 to 14 days (Table 1). About 3 to 4 weeks after transplanting (19 May 2006 for trial 1; 14 November 2006 for trial 2 ), two colonized rice grains were placed in each of three holes around the edge of the root system about $4 \mathrm{~cm}$ below the surface. Plants at the field lab were watered by sprinkler irrigation, while seedlings in the greenhouse trial were given drip irrigation (Fig. 1). Plants were observed for foliar symptoms of root rot and rated as: 1 =no disease; 2 = slight disease (slight needle chlorosis); $3=$ moderate to severe (moderate chlorosis and/ or necrosis); and $4=$ dead plant. Plants were harvested 21 and 30 weeks after inoculation for trial 1 and 2 , respectively, except as described below for trial 2. At harvest, top weight was assessed and root systems of each plant were rated on a scale of 1 to 5 (with $1=$ healthy; $2=$ up to $25 \%$ of root system necrotic; $3=$ up to $50 \%$ of root system necrotic; $4=$ more than $50 \%$ of root system necrotic; and $5=$ dead plants, all roots necrotic). ANOVA analyses of mean top weight and root rot ratings were made following the GLM procedure in SAS (SAS v. 9.1, SAS Institute Inc., Cary, NC).

Table 1. Source of Phytophthora cinnamomi and Pythium vexans isolates used in the pathogenicity trials

\begin{tabular}{|l|l|}
\hline I solate (I D)* & Source \\
\hline Pythium vexans (Ph565) & G. Abad \\
\hline Pythium vexans (Ph564) & G. Abad \\
\hline Pythium vexans (Ph546) & G. Abad \\
\hline Pythium vexans (Buch1A1) & B. Richter \\
\hline Phytophthora cinnamomi (2378) & D. M. Benson \\
$\begin{array}{l}\text { * All isolates originated from Fraser fir plants growing in North Carolina } \\
\text { and were identified by culture morphology and ITS sequence. }\end{array}$
\end{tabular}

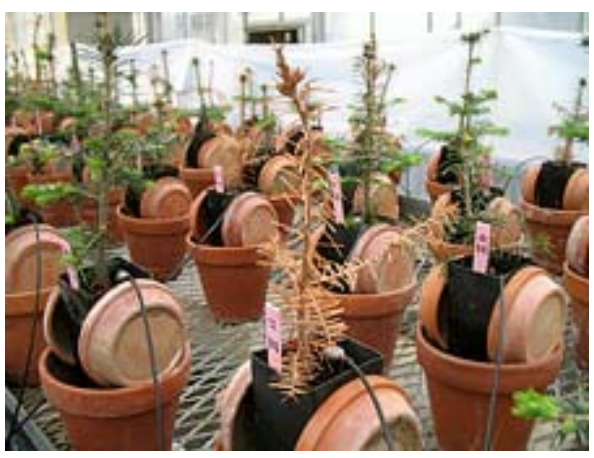

Fig. 1. Set up of pathogenicity trial 2 conducted in the greenhouse. Dead seedling in the foreground had been inoculated with the combination of Phytophthora cinnamomi and Pythium vexans.

\section{Pathogenicity Results, Trial 1}

Foliar symptoms of Phytophthora root rot began to show up on plants in the Phytophthora cinnamomi and Phytophthora cinnamomi plus Pythium vexans treatments about 6 weeks after inoculation (data not shown). Within 8 weeks of inoculation, only plants inoculated with P. cinnamomi or the combination with P. vexans had significantly higher foliar disease ratings than the non-inoculated 
control (Table 2, Fig. 2, Fig. 3). By 4 August 2006, all Fraser fir plants inoculated with Phytophthora cinnamomi were dead but fir inoculated with $P$. vexans appeared healthy. At harvest on 16 October 2006, top weight and root rot ratings of fir plants inoculated with $P$. vexans were not significantly different from those of non-inoculated plants. In comparison, plants inoculated with Phytophthora cinnamomi or Phytophthora cinnamomi with P. vexans in combination had smaller top weights and significantly higher root rot ratings in comparison to non-inoculated plants.

Table 2. Mean disease ratings and top weights of Fraser fir seedlings among treatments evaluated in Trial $1^{\mathrm{w}}$.

\begin{tabular}{|l|l|l|c|c|c|c|c|}
\hline \multirow{2}{*}{ Treatment } & & \multicolumn{3}{|c|}{ Foliar rating (1 to 4$)^{\mathrm{x}}$} & \multicolumn{2}{|c|}{ Harvest $^{\mathrm{y}}$} \\
\cline { 3 - 8 } & & $\begin{array}{c}8 \\
\text { I solate }\end{array}$ & $\begin{array}{c}6 \\
\text { Jun }\end{array}$ & $\begin{array}{c}4 \\
\text { Jul }\end{array}$ & $\begin{array}{c}7 \\
\text { Aug }\end{array}$ & $\begin{array}{c}\text { Top wt } \\
\text { Sep }\end{array}$ & $\begin{array}{c}\text { Root } \\
\text { rot }\end{array}$ \\
\hline Non-inoculated control & & 1.2 & $1.4 \mathrm{~b}^{\mathrm{z}}$ & $1.5 \mathrm{c}$ & $1.5 \mathrm{~b}$ & $4.1 \mathrm{~b}$ & $1 \mathrm{~b}$ \\
\hline Phytophthora cinnamomi & 2378 & 1.2 & $3.5 \mathrm{a}$ & $4.0 \mathrm{a}$ & $4.0 \mathrm{a}$ & $0.5 \mathrm{c}$ & $5 \mathrm{a}$ \\
\hline Pythium vexans & Ph565 & 1.2 & $1.1 \mathrm{~b}$ & $1.4 \mathrm{c}$ & $1.3 \mathrm{~b}$ & $4.4 \mathrm{~b}$ & $1.4 \mathrm{~b}$ \\
\hline P. vexans & Ph564 & 1.1 & $1.2 \mathrm{~b}$ & $1.5 \mathrm{c}$ & $1.5 \mathrm{~b}$ & $6.9 \mathrm{a}$ & $1.0 \mathrm{~b}$ \\
\hline P. vexans & Ph546 & 1.1 & $1.3 \mathrm{~b}$ & $1.4 \mathrm{c}$ & $1.7 \mathrm{~b}$ & $5.0 \mathrm{ab}$ & $1.6 \mathrm{~b}$ \\
\hline P. vexans & Buch1A1 & 1.0 & $1.0 \mathrm{~b}$ & $1.4 \mathrm{c}$ & $1.7 \mathrm{~b}$ & $4.0 \mathrm{~b}$ & $1.6 \mathrm{~b}$ \\
\hline $\begin{array}{l}\text { P. vexans + Phytophthora } \\
\text { cinnamomi }\end{array}$ & $\begin{array}{l}\text { Ph565 }+ \\
2378\end{array}$ & $1.3 \mathrm{~ns}$ & $3.6 \mathrm{a}$ & $3.6 \mathrm{~b}$ & $3.7 \mathrm{a}$ & $0.6 \mathrm{c}$ & $4.4 \mathrm{a}$ \\
\hline
\end{tabular}

${ }^{\mathrm{w}}$ All values in table are the means of 14 replications.

Foliar rating scale: 1 = no disease; 2 = slight disease (slight chlorosis): 3 = moderate to severe (moderate chlorosis/necrosis); and $4=$ dead plant.

y At harvest on 16 October 2006, fresh top weight was assessed and root systems rated as: $1=$ healthy; $2=$ up to $25 \%$ of root system necrotic; $3=$ up to $50 \%$ of root system necrotic; $4=$ more than $50 \%$ of root system necrotic; and $5=$ dead plants, all roots necrotic.

$\mathrm{z}$ Means within a column followed by the same letter are not different according to the Waller-Duncan $\mathrm{k}$ ratio test, $\mathrm{k}=100, \mathrm{P}=0.05$. ns $=$ not significant.

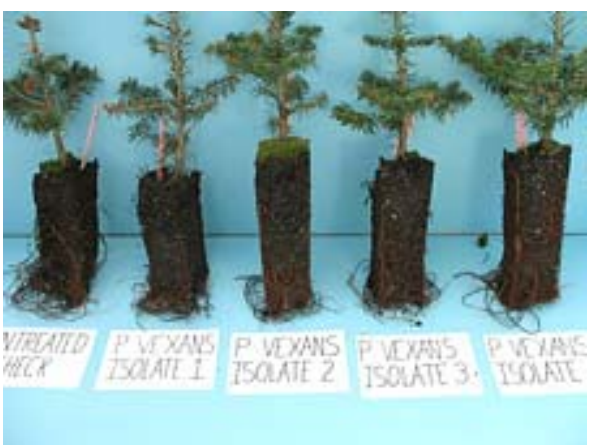

Fig. 2. Appearance of healthy Fraser fir seedlings at harvest on 12 June 2007 after inoculation with Pythium vexans isolates Ph565 (isolate 1), Ph564 (isolate 2), Ph546 (isolate 3 ), Buch1A1 (isolate 4), or noninoculated (untreated check).

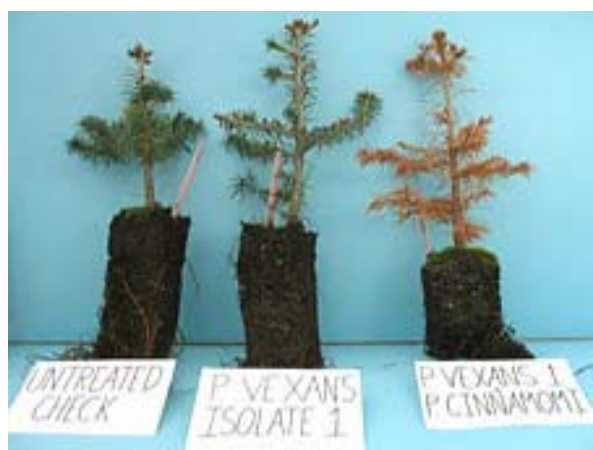

Fig. 3. Appearance of a non-inoculated Fraser fir seedling compared to those inoculated with Pythium vexans isolate Ph565 or co-inoculated with Phytophthora cinnamomi plus $\mathrm{P}$. vexans at harvest on 12 June 2007.

For plants that had died by 28 August 2006, roots were rinsed to remove adhering potting mix, blotted dry, and cultured on $\mathrm{P}_{10} \mathrm{ARP}$. For the Phytophthora cinnamomi treatment, the pathogen was recovered from 11 of 13 dead firs. No mortality was observed in fir inoculated with $P$. vexans isolates Ph565 and Ph564 by 28 August, although one plant was dead in each of the treatments with $\mathrm{P}$. vexans isolates $\mathrm{Ph} 546$ and Buch1Al. P. vexans was recovered from each dead plant along with an unidentified semi-papillate Phytophthora sp., which may have been introduced from other trials in the area or on the original fir seedling. 
After harvest, roots of surviving firs were cultured on $\mathrm{P}_{10} \mathrm{ARP}$ and examined to detect Phytophthora and/ or P. vexans. Neither organism was recovered from roots of non-inoculated controls. For plants inoculated with isolate Ph565, P. vexans was recovered from four asymptomatic plants, although no Phytophthora sp. or other Pythium sp. was detected from the remaining 10 plants. For plants inoculated with isolate Ph564, P. vexans was recovered from three asymptomatic plants, although no Phytophthora sp. or other Pythium sp. was detected from the remaining 11 plants. For treatments with isolate Ph546, P. vexans was recovered from four plants; with isolate Buch1A1, P. vexans was recovered from eight plants but not from two other plants that had died in this treatment. All plants except two plants in the combination treatment were dead and $P$. vexans was recovered from one and Phytophthora cinnamomi from neither of the two living plants.

\section{Pathogenicity Results, Trial 2}

Fraser fir seedlings in this trial had not undergone a winter cold exposure prior to setting up the greenhouse test, therefore, little new top growth developed throughout the study. However, abundant root growth occurred in the potting medium and roots eventually developed quite extensively in the bottom of the clay pot used to support the Anderson band (Fig. 1). Seedlings in treatments with Phytophthora cinnamomi had severe foliar ratings within 30 days of inoculation (Table 3). Mean foliar ratings for seedlings in the noninoculated control and in all treatments with $\mathrm{P}$. vexans were near 1 (healthy) throughout the trial (Table 3).

Table 3. Mean disease ratings and top weights of Fraser fir seedlings among treatments evaluated in Trial 2. ${ }^{\mathrm{V}}$

\begin{tabular}{|c|c|c|c|c|c|c|}
\hline \multirow[b]{2}{*}{ Treatment } & \multirow[b]{2}{*}{ I solate } & \multicolumn{3}{|c|}{ Foliar rating ( 1 to 4$)^{x}$} & \multicolumn{2}{|c|}{ Harvest $^{\mathrm{y}}$} \\
\hline & & $\begin{array}{c}22 \\
\text { Dec }\end{array}$ & $\begin{array}{l}23 \\
\text { Jan }\end{array}$ & $\begin{array}{c}30 \\
\text { Apr }\end{array}$ & $\begin{array}{l}\text { Top } \\
\text { wt }(g)\end{array}$ & $\begin{array}{l}\text { Root } \\
\text { rot }\end{array}$ \\
\hline Non-inoculated control & & $1.0 \mathrm{~b}^{\mathrm{z}}$ & $1.0 \mathrm{~b}$ & $1.0 \mathrm{~b}$ & $49 a$ & $1.2 \mathrm{~b}$ \\
\hline Phytophthora cinnamomiw & 2378 & $3.0 \mathrm{a}$ & $3.5 \mathrm{a}$ & $3.7 \mathrm{a}$ & $13 \mathrm{~b}$ & $4.6 a$ \\
\hline Pythium vexans & Ph565 & $1.0 \mathrm{~b}$ & $1.0 \mathrm{~b}$ & $1.0 \mathrm{~b}$ & $50 a$ & $1.3 \mathrm{~b}$ \\
\hline P. vexans & Ph564 & $1.1 \mathrm{~b}$ & $1.1 \mathrm{~b}$ & $1.1 \mathrm{~b}$ & $45 \mathrm{a}$ & $1.2 \mathrm{~b}$ \\
\hline P. vexans & Ph546 & $1.1 \mathrm{~b}$ & $1.1 \mathrm{~b}$ & $1.1 \mathrm{~b}$ & $45 \mathrm{a}$ & $1.4 \mathrm{~b}$ \\
\hline P. vexans & Buch1A1 & $1.0 \mathrm{~b}$ & $1.0 \mathrm{~b}$ & $1.0 \mathrm{~b}$ & $44 a$ & $1.9 \mathrm{~b}$ \\
\hline $\begin{array}{l}\text { P. vexans }+ \\
\text { Phytophthora cinnamomiw }\end{array}$ & $\begin{array}{l}\mathrm{Ph} 565+ \\
2378\end{array}$ & $3.5 \mathrm{a}$ & $3.7 \mathrm{a}$ & $3.7 \mathrm{a}$ & $12 \mathrm{~b}$ & $4.6 \mathrm{a}$ \\
\hline
\end{tabular}

$\checkmark$ All values in table are the means of 10 replications.

w Seedlings that had died by 9 January 2007 were harvested, weighed and given a root rot rating of 5 . This included eight of 10 seedlings in the treatment with Phytophthora cinnamomi and nine of 10 seedlings in the treatment with $\mathrm{P}$. vexans plus Phytophthora cinnamomi.

x Foliar rating scale: 1 = no disease; 2 = slight disease (slight chlorosis); $3=$ moderate to severe (moderate chlorosis necrosis); $4=$ dead plant.

y At final harvest on 12 J une 2007, fresh top weight was assessed and root systems of remaining seedlings rated as: $1=$ healthy; $2=$ up to $25 \%$ of root system necrotic; $3=$ up to $50 \%$ of root system necrotic; $4=$ more than $50 \%$ of root system necrotic; and $5=$ dead plants, all roots necrotic.

$\mathrm{z}$ Means within a column followed by the same letter are not different according to the Waller-Duncan $\mathrm{k}$ ratio test, $\mathrm{k}=100, \mathrm{P}=0.05$.

Most of the fir seedlings in treatments with Phytophthora cinnamomi were dead by $9 \mathrm{~J}$ anuary 2007; this included eight of 10 seedlings (nine of 10 by 7 May) in the treatment with Phytophthora cinnamomi and 9 of 10 seedlings in the combination treatment of P. vexans plus Phytophthora cinnamomi. Dead seedlings were weighed and roots cultured. Phytophthora cinnamomi was recovered from roots of all dead seedlings. P. vexans was co-recovered from one 
seedling in the combination treatment. No fir seedlings in any other treatment had died by $9 \mathrm{~J}$ anuary 2007.

Mean top weights for the most of the dead fir seedlings in treatments with Phytophthora cinnamomi were approximately $12 \mathrm{~g}$ per plant compared to about $45 \mathrm{~g}$ per plant for seedlings in the non-inoculated control and all isolates of $\mathrm{P}$. vexans (Table 3). Top growth and plant survival were reflections of root rot severity; e.g., seedlings in treatments with Phytophthora cinnamomi and Phytophthora cinnamomi plus P. vexans, which had 90\% mortality, had mean root rot ratings of 4.6, whereas seedlings in the non-inoculated control and treatments with $P$. vexans alone, which all survived, had mean root rot ratings of 1.3 .

After final harvest on $12 \mathrm{~J}$ une, roots from a sub-set of three to six remaining seedlings per treatment were cultured on $\mathrm{P}_{10} \mathrm{ARP}$. $\mathrm{P}$. vexans was isolated from two of the three living seedlings that had been inoculated with isolate Ph546 and from one of the six remaining seedlings that had been inoculated with Buch1A1. $\mathrm{P}$. vexans was not recovered from seedlings in treatments with isolates Ph565 and Ph564.

\section{Pythium vexans: A Saprobe on Fir}

Pythium vexans has been reported to cause patch canker disease of the trunks and roots of rubber trees in China (12), yet several publications have disputed its pathogenicity on a number of hosts $(3,6,7,11)$. Under the conditions of these tests, our results indicate that the four isolates of $P$. vexans examined in these trials did not cause mortality or root rot symptoms on Fraser fir. In comparison, Phytophthora cinnamomi caused severe root rot symptoms in all plants. These experiments provided no evidence for pathogenicity of P. vexans on Fraser fir. It would be advisable for future studies to examine the possible roles of soil water saturation or flooding in the development of root disease caused by $\mathrm{P}$. vexans on this host.

\section{Acknowledgments}

The research was funded through the North Carolina Christmas Tree Association. The donation of Fraser fir plugs by the NC Forest Service is appreciated. We thank Tom Creswell and Charles Hodges of the NC State University Plant Disease and Insect Clinic for providing initial diagnoses of fir samples, and Kala Parker, Brantlee Richter, and Billy Daughtry for help with the pathogenicity trials.

\section{Literature Cited}

1. Benson, D. M., Grand, L. F., and Suggs, E. G. 1976. Root rot of Fraser fir caused by Phytophthora drechsleri. Plant Dis. Rep. 60:238-240.

2. Benson, D. M., and Grand, L. F. 2000. Incidence of Phytophthora root rot of Fraser fir in North Carolina and sensitivity of isolates of Phytophthora cinnamomi to metalaxyl. Plant Dis. 84:661-664.

3. Hendrix, F. F., and Campbell, W. A. 1973. Pythiums as plant pathogens. Ann. Rev. Phytopath. 11:77-98.

4. Kuhlman, E. G., and Hendrix, F. F., J r. 1963. Phytophthora root rot of Fraser fir. Plant Dis. Rep. 47:552-553.

5. Kanwischer, M. E., and Mitchell, D. J . 1978. The influence of a fungicide on the epidemiology of black shank of tobacco. Phytopathology 68:1760-1765.

6. Kliejunas, J. T., and Ko, W. H. 1975. The occurrence of Pythium vexans in Hawaii and its relation to ohia decline. Plant Dis. Rep. 59:392-395.

7. Mulder, D. 1969. The pathogenicity of several Pythium species to rootlets of apple seedlings. Eur. J. Plant Pathol. 75:178-181.

8. NASS-USDA. 2007. Nursery crops 2006 summary. Pub no. Sp Cr 6-3 (07). Natl. Agric. Stat. Serv. (NASS), USDA, Washington, DC.

9. Shafizadeh, S., and Kavanagh, J. A. 2005. Pathogenicity of Phytophthora species and Pythium undulatum isolated from Abies procera Christmas trees in Ireland. For. Path. 35:444-450.

10. Shew, H. D., and Benson, D. M. 1981. Fraser fir root rot induced by Phytophthora citricola. Plant Dis. 65:688-689. 
11. Vawdrey, L. L., Langdon, P., and Martin, T. 2005 Incidence and pathogenicity of Phytophthora palmivora and Pythium vexans associated with durian decline in far northern Queensland. Australas. Plant Pathol. 34:127-128.

12. Zeng, H. C., Ho, H. H., and Zeng, F. C. 2005. Pythium vexans causing patch canker of rubber trees on Hainan Island, China. Mycopathologia 159:601-606. 